\title{
Public and Elite Views on Europe vs. China in Africa ${ }^{1}$
}

\author{
Lorenzo Fioramonti \\ Research Unit for Euro-African Studies \\ Department of Political Sciences \\ University of Pretoria, South Africa \\ Patrick Kimunguyi Monash \\ University, Australia
}

\author{
Correspondence details: \\ Lorenzo Fioramonti \\ Department of Political Sciences \\ University of Pretoria \\ Lynwood Rd \\ 0002 - Pretoria \\ South Africa \\ Email: Lorenzo.fioramonti@gmail.com
}

\section{ABSTRACT}

Europe has been the privileged economic and political partner of Africa, but more recently China has increased its foothold in Africa through important financial investments and trade agreements. Against this backdrop, our empirical research conducted in 2007-2008 in Kenya and South Africa as part of a pioneering international project investigates the perceptions of public opinion, political leaders, civil society activists and media operators. While confirming their continent's traditional proximity to Europe, African citizens are increasingly interested in China and its impact on Africa's development. While African civil society leaders and media operators describe China as an opportunity for Africa to break free from its historical dependence on European markets, other opinion leaders warn against too much enthusiasm with the Asian giant. On the one hand, Europe is increasingly criticized for not having been able to dismiss the traditionally 'patronizing' attitude towards Africa. On the other hand, China is expected to bring a breath of fresh air into the African context, although there is still suspicion that the Chinese strategy might, in the long run, turn into a new form of economic patronage.

Key words: European Union; China; Africa; perceptions; trade; colonialism.

\section{Introduction}

Traditionally, Europe has been the privileged economic and political partner of Africa. Strong ties have outlived colonialism and have permeated the past 50 years of Europe-Africa relations. More recently, China has increased its foothold in Africa through important financial investments, trade agreements and energy-related partnerships. In few years, the Chinese presence in the hitherto European 'backyard' has made an unprecedented impact in terms of economic growth and infrastructure building. These recent developments seem to have called into question the privileged position the EU has

\footnotetext{
${ }^{1}$ This article is the outcome of a collaborative effort. Nevertheless, Patrick Kimunguy elaborated the sections on Kenya,
} while Lorenzo Fioramonti authored those on South Africa. Sections 1, 2 and 4 were elaborated jointly. 
been enjoying in Africa since the end of colonialism. As recently as 2007, some African countries strongly criticised a new trade regime with the EU (the so-called Economic Partnership Agreements) and openly attacked the European interference with African internal governance issues. ${ }^{2}$ Simultaneously, African leaders have praised the Chinese involvement in the continent for its massive scale of investment and its lack of conditionality measures. As remarked by Senegalese President Abdoulaye Wade during a visit to the EU in 2009, "Europe is less and less attractive for Africa", especially now that emerging markets like China offer "much more competitive conditions" to African countries. ${ }^{3}$

Against this backdrop, this article looks at how elites and public opinion view the role of the EU and China in two key African countries: Kenya and South Africa. Both these countries are major economic and political players in their regions (East Africa and Southern Africa, respectively) and are key commercial and political partners of both the EU and China.

Our research methodology focused on two main data sources: (a) a series of face-to-face interviews with 32 elites in each country, including parliamentary representatives of all major parties, leaders of civil society organizations and trade unions, top representatives of the business sector and news editors of the main TV channels and newspapers; (b) two public opinion surveys. ${ }^{4}$ The article is organized as follows. Section 2 provides an brief description of the political and economic relations between Africa and the EU and China respectively. Section 3 discusses the findings of our research, dividing the analysis into two parts: elites and public opinion. Finally, Section 4 provides some concluding remarks.

\section{Africa, the EU and China}

In recent years, the relationship between Africa, on the one hand, and Europe and China, on the other hand, has experienced significant changes in terms of policies and main actors involved.

Within the Euro-African context, the pas decade has seen major reforms at different levels. The trade and development paradigm represented by the 25-year-long preferential regime of the Lomé convention has been replaced by the Cotonou agreement, thereby paving the way to market liberalization under the auspices of the World Trade Organization (WTO). ${ }^{5}$

\footnotetext{
${ }^{2}$ In December 2007, most African leaders stigmatized the initial European opposition to the participation of Zimbabwean President Robert Mugabe to the EU-Africa summit in Lisbon threatening to boycott the meeting.

3 Authors' translation from an interview with Der Standard, 24 June $2009<$ http:// derstandard.at/1245820005269/Praesident-kritisiert-Afrika-Politik-der-EU>.

${ }^{4}$ This research is part of the international project "External Perception of the EU", sub-project "The Visibility of the European Union as a Development Actor in South and East Africa, South East Asia and the Pacific" (2006-on going), coordinated by the National Centre for Research on Europe (NCRE) at the University of Canterbury, New Zealand. We thank all our colleagues at the NCRE for their support, comments and invaluable guidance. The public opinion survey in Kenya is from the Afrobarometer conducted in 2008 (www.afrobarometer.org).

5 The Cotonou agreement was signed between the European Union and 78 African, Caribbean and Pacific (ACP) states.
} 
Moreover, the creation of the African Union (AU) in 2002 and a new series of EU military missions in Africa since 2003 have marked a turning point for Europe-Africa relations from both a political and military point of view. There is no doubt that the European Union (EU) is a reference point for policymakers involved in regional integration processes in Africa. Since the establishment of the AU, the close connection with the European 'best practice' has been made explicit in a series of documents, public statements and declarations. ${ }^{6}$ The so-called 'grand debate' on the government of the AU, which occupied centre stage at the Accra meeting in July 2007, was an opportunity for heads of state, analysts and opinion makers to discuss whether or not Africa should follow Europe's footsteps. Such a close relationship has led, in 2007-2008, to the adoption of the Africa-EU Strategic Partnership.

At the same time, though, this 'partnership' has also come under strain in the past few years. Trade reforms, especially concerning the adoption of the so-called Economic Partnership Agreements (EPAs), have generated widespread resentment in Africa elites and open criticism throughout the African media. The EPAs have come under fire from different quarters, usually in combination with 'fortress Europe' arguments regarding agricultural protectionism, commonly regarded as distorting EU-Africa trade flows to the advantage of European farming industries. The EPAs have also driven a wedge between African 'least developed countries' (LDCs), which already have duty free access to the EU market through the "Everything but Arms" (EBA) programme and other African states, which have seen their hitherto preferential access downgraded to the generalized system of preferences (GSP), which exempts some developing countries from the full application of WTO rules.

During the last decade, China's growing presence in Africa has been at the centre of political, economic and journalistic attention. In the general media, the Chinese involvement in Africa is often described as entrepreneurial and development oriented, while in other cases it is denounced as neo-imperialistic, with China joining the race in a 'new scramble' for Africa's resources. ${ }^{7}$

Undoubtedly, China has emerged to become one of Africa's most significant development and trade partner. According to the United Nations Cooperation on Trade and Development (UNCTAD), the exports and imports between the two rose from USD 1 billion in 2000 to USD 56 billion in 2006. ${ }^{8}$ At the same time, African exports to Asia (mainly China) increased by 20 percent in the period between 2000 and 2005. As a share of Africa's total exports, Asia rose from 9 percent to in 1990 to 27 percent in 2005. At the same time exports to traditional markets, such as former colonial powers of Europe, decreased from approximately 48 percent to 32 percent. $^{9}$

China's competitiveness can be felt also in the area of development cooperation. A recent report by McKinsey Global Institute highlights that "since 2005, China's total infrastructure commitments in sub-Saharan Africa have exceeded the World Bank's

\footnotetext{
6 See Sicurelli, Regional Partners? Perceptions and Criticisms at the African Union.

${ }^{7}$ Southall and Melber, A New Scramble for Africa?

${ }^{8}$ UNCTAD, Asian Foreign Direct Investment in Africa.

${ }^{9}$ Broadman, Africa's Silk Road, 66.
} 
infrastructures commitments"10. On the other side of the Mediterranean, the EU and some of its member states have been quick to complain about the negative impact of China's increasing economic and political influence in sub-Saharan Africa, highlighting how Chinese business is displacing African local production and arguing that China would largely free-ride on the debt-relief efforts of Western donors. ${ }^{11}$ Nevertheless, African political leaders have been keen on strengthening and upgrading economic ties with the Asian giant (also at the cost of facing fierce competition by Chinese exporting firms) and China has also become a strong political, cultural and social partner for many governments, as epitomized by the widely heralded tour that brought President $\mathrm{Hu}$ Jintao to sub-Saharan Africa in 2007. Moreover, as remarked by the Financial Times, the sight of large delegations from African capitals to Beijing has now become "commonplace". ${ }^{12}$ The latest of such visits was led by South African President Jacob Zuma in August 2010, exceptionally accompanied by 11 cabinet members (the biggest group yet to accompany a South African leader abroad) and almost 400 business executives. ${ }^{13}$ According to South Africa Trade Minister, Rob Davies, China's rapidly expanding African presence "can only be a good thing" because it means increased competition between developed and developing countries in their pursuit of resources and influence in Africa. ${ }^{14}$

Senegalese President Wade, once again interpreted a rather widespread opinion among his continental counterparts when he affirmed that when it comes to Africa "the European Union and the US want to have their cake and eat it too":

China, which has fought its own battles to modernise, has much greater sense of personal urgency of development in Africa than many Western nations... Not just Africa but the West itself has much to learn from China. It is time for the West to practise what it preaches about the value of market incentives. ${ }^{15}$

However, there is some fear that the presence of China in Africa and the soaring import of Chinese products might have adverse effects on the nascent industries in the African LDCs and exert more pressure on the most fragile economies. In Angola, which is the most important African partner for Chinese extractive industries, most of the big development projects, financed and managed by the China International Fund (CIF), have been halted because of gross mismanagement, and the Angolan government has cancelled the contracts. ${ }^{16}$ Thus, in spite of an important increase in China's official relations with Africa, its presence has not been immune from criticism by experts, researchers, academics and policy makers. ${ }^{17}$ In 2006, former South African President Thabo Mbeki warned that Africa might be falling into another "colonial relationship" with China. ${ }^{18}$

Finally, it is worth mentioning that both the EU and China have indicated a willingness to extend their bilateral cooperation on African issues, for example by launching the EU-Africa-China trilateral dialogue. The first meeting was held in Brussels

\footnotetext{
${ }^{10}$ Roxburg, Lions on the Move, 15.

${ }^{11}$ Kaplinsky and Morris, "China and the Terms of Trade". Reisen and Ndoye, "Prudent versus Imprudent".

${ }^{12}$ FT.com, China's New Scramble for Africa.

13 Anderlini, Pretoria Defends China's Africa Policy.

14 Ibid.

${ }^{15}$ Wade, "Time for the West to Practise what it preaches", 20.

16 Serge, "En Angola son premier partenaire africain".

17 Kernen, "Les strategies chinoises en Afrique" and Sylvanus, "Chinese Devils".

18 See http://news.bbc.co.uk/2/hi/business/6178897.stm.
} 
on 28 June 2007 where 180 experts and representatives from Europe, Africa, and China came together under the same roof for the first time to discuss how these three 'stakeholders' could cooperate as partners. As Marie-Martine Buckens notes, Europe aims to preserve the privileged relationship it has enjoyed with Africa for decades and the meeting was organized to "avert a clash between Africa's leading trading partner and investor and a nation [China] that has become the continent's third largest trading partner in the period of three years"19. As stated by the former EU Commissioner for Development and Humanitarian Aid, Louis Michel, in his opening remarks: "we are competitors, but we are also partners and Africa should benefit rather than suffer from our presence" ${ }^{20}$

\section{Perceptions of EU and China: evidence from Kenya and South Africa}

Building on the historical and political developments discussed in the previous section, we now turn to the findings of our empirical research. Kenya and South Africa were selected as two important case studies for political, economic and geographical reasons. First of all, both countries are major powerhouses in the sub-Saharan context. Secondly, these countries have strong political and economic ties to both the EU and China, which consider them as regional gatekeepers. Thirdly, Kenya and South Africa represent two important sub-regions in the continent: East Africa and Southern Africa respectively. As already explained in the introduction, our data is divided into two groups: national elites (politicians, business leaders, media operators and civil society groups) and public opinion.

Figure 1 - Is the EU more or less important for your country than other regions?

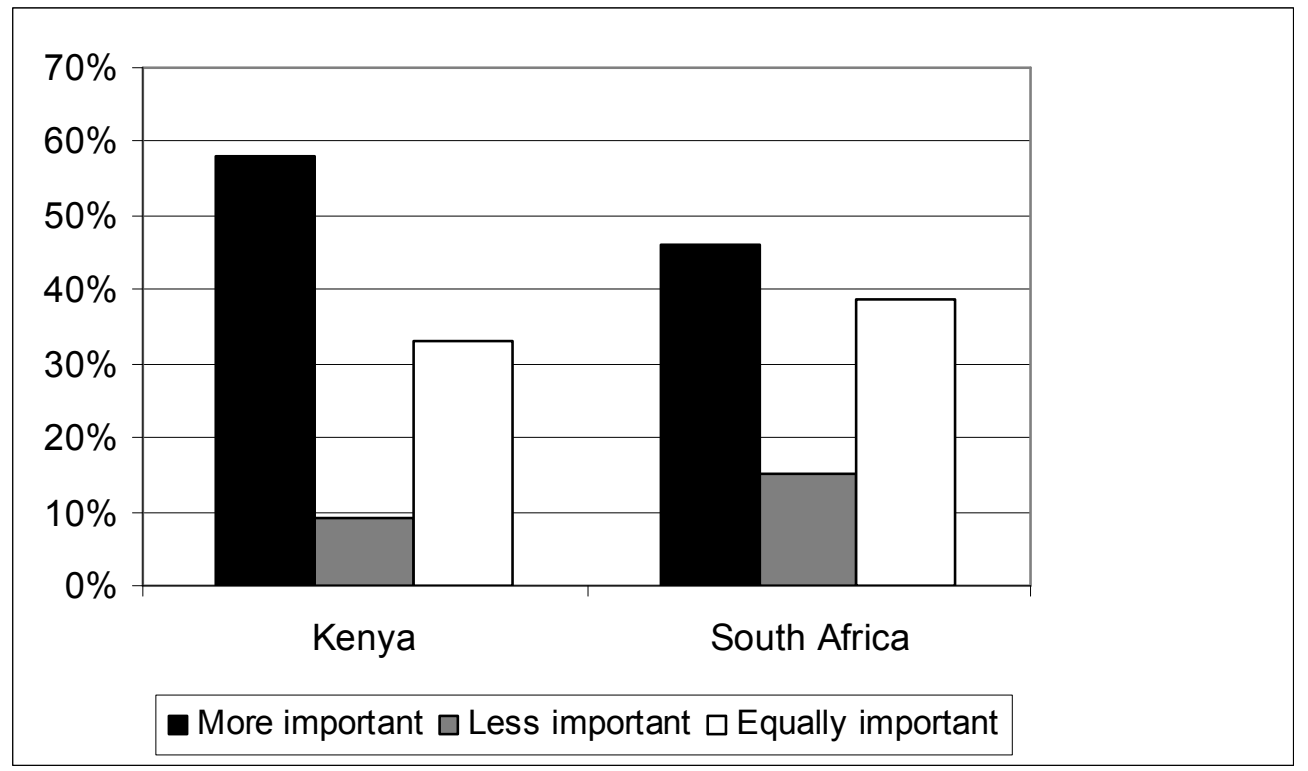

Source: National Centre for Research on Europe

19 Buckens, “EU-Africa-China”.

20 Ibid. 


\subsection{Elite perceptions}

We interviewed 64 respondents (32 in each country) among prominent parliamentarians, business leaders, media editors and civil society leaders in Kenya and South Africa. ${ }^{21}$ First of all, our respondents were asked to assess whether the EU was the more or less important than other regions of the world. The overall results are represented in Figure 1.

In Kenya, the EU is viewed as more important than other regions by the majority of survey respondents (58\%), while a small minority (9\%) regard it as 'less important', with about a third rating it as equally important as any other region. Trade relations and economic linkages are mentioned as the top reasons for such a privileged status. Yet, a number of respondents also hold critical views of this relationship. Although they recognize the importance of the EU throughout history (mainly due to the EU-ACP relationship since the Lomé Convention), some of them express concern about the future EU-Kenya relationship, particularly in areas such as democratic governance and security. ${ }^{22}$

As observed by Alex Chamwada of Kenya Television Network, the EU-Kenya privileged relationship was negatively affected by the civil conflict erupted in the aftermath of the presidential elections of December 2007, which brought the security issue back on the Kenyan agenda. He noted that "in the light of this violence, the EU may not execute its projects" and this might have serious implications, also in the rest of the regions, "from the Horn of Africa to the Great Lakes." 23 A similar view was expressed by Seth Adams of World Vision, who admitted that the EU-Kenya relationship was already suffering because of the political crisis in the country and the suspension of development cooperation programmes by the EU. He noted that the EU is important to Kenya and Africa especially when it comes to development projects: "We have had quite a number of projects scattered around the country, including such programmes like free primary and secondary education. But now with the threatening of sanctions we are likely to have limited support from the European Commission." 24 While the EU was broadly appreciated by the Kenyan business community, both civil society and the media were more critical of certain EU policies, especially in the field of trade, with a number of respondents pointing to the EU position in the Doha Round and the "heavy-handed" negotiations of the EPAs.

A similar trend is visible in the case of South Africa (Figure 1). The EU is deemed to be more important than other regions by $46 \%$ of respondents, although $39 \%$ are convinced it is neither more nor less important than other global players. Only $15 \%$ believe it is less important. In this country, too, the EU is appreciated by business elites and parliamentarians, who emphasize the longstanding economic and political relationship between Europe and Africa. By contrast, media operators and civil society leaders are

\footnotetext{
21 The parliamentarians interviewed were generally the foreign affairs spokespersons of the major political parties. Whenever possible, we tried to interview an equal number of MPs from majority and opposition parties.

22Interviews for this study were conducted between February and May 2008. At that time Kenya was undergoing political turmoil and civil conflict, which resulted from the contested general elections of 28-29 December 2007.

${ }^{23} \mathrm{Mr}$. Alex Chamwada, Political News Editor, Kenya Television Network (KTN). Interviewed in Nairobi on 30 January 2008.

${ }^{24} \mathrm{Mr}$. Seth Adams, Manager, World Vision Sudan. Interviewed in Webuye on 9 January 2008.
} 
more sceptical of the EU's role. They strongly criticize European trade policies towards Africa, which some of them characterize as 'neo-colonialism'. All respondents, including those who hold more positive views of the EU, stigmatize its agricultural policy and openly attack the subsidy regime imposed by European institutions on certain products, which they see as having a distorting effect on trade between Africa and Europe.

When we move from the individual assessment of the EU to a comparative evaluation between Europe and other regions of the world, the picture begins to change, at least partly. Figure 2 shows that a number of regions are challenging the privileged economic and political relationship that the EU has been enjoying with Africa in the past decades.

According to South African elites, China is becoming more and more important to their country. For more than $37 \%$ of respondents, China is seriously eroding EU's power in South Africa and, as a consequence, in Africa. The eastern giant is followed by India (35\%) and the USA (15\%). In light with the spirit of the 'African reinassance', $12.5 \%$ of respondents believe that intra-African relations are slowly replacing the EU-Africa partnership. ${ }^{25}$

Figure 2 - What other regions are (or might become) more important than the EU?

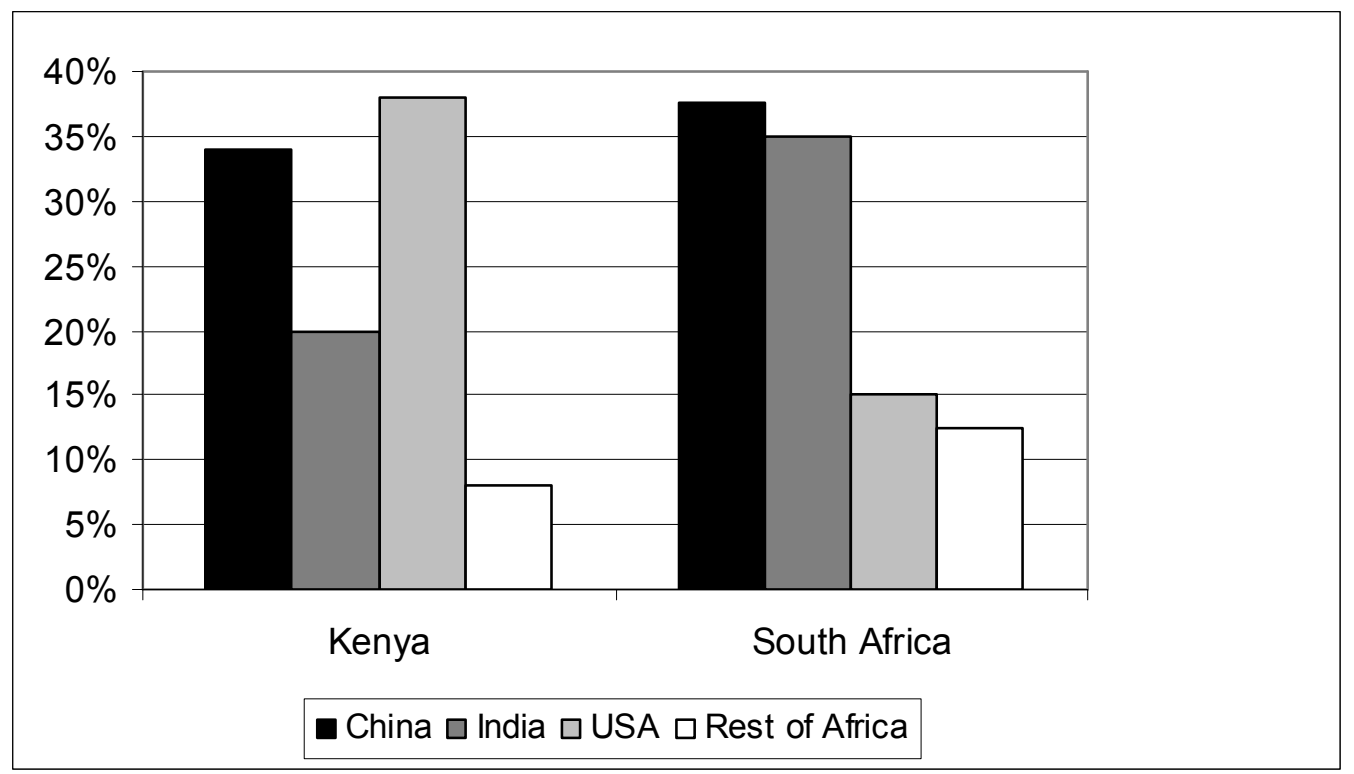

Source: National Centre for Research on Europe

In the words of P.J. Botha of the Emerging Market Focus, a South African think tank, Africa fell off the international agenda after the end of the Cold War: "It was only with the entrance of China and India and with the massive need to develop new energy resources, that Africa was put back on the agenda. [...] Suddenly we have become more important also to the EU." 26 Similarly, the foreign news editor of the South African prime magazine The Mail \& Guardian, N. Dollie, maintains that "China has got more of a status in Africa

25 The expression 'African renaissance' has been often used by former South African President, Thabo Mbeki, to describe the internal African economic, political and cultural revival, which has long been a priority policy for the South African government.

26 P.J. Botha, Emerging Market Focus. Interview held in Pretoria (South Africa) on 28 November 2007. 
than the EU. Simply because its history with African people is not connected with colonialism or neo-colonialism. They are investing a lot in Africa. Their conditions, however, are very different. They are saying: We are doing investment without questioning the integrity of your political systems. Political benefits will come when economic benefits accrue." 27

The growing trade volumes and investment flows from Beijing to the African continent are viewed by our South African respondents as evidence of a differentiation of economic partners that can only benefit Africa. Yet, some respondents caution against excessive optimism regarding China in Africa. For instance, General Bantu Holomisa, leader of the United Democratic Movement, believes that although "China is now trying to influence the African continent, we are miles ahead with the European Union". Similarly, Johan De Bruyn of the South African Chamber of Commerce does not think that the EU is being 'replaced' by the Eastern giant: "China's business culture is not the same as the European culture. South Africa is much more acquainted with the European system."

Perhaps the most telling summary of the perceived risks posed by China is provided by MP Geoff Doidge of the African National Congress:

China tends to act more unilaterally, [...] but when it comes to the broader issues of the continent, they are going to find themselves in an awkward situation. I don't see it succeeding, because you have got to feed into this bigger plan. Changes and reforms must therefore be integrated into the greater plan and Europe accepts that. There is no doubt that things are rising very fast in the East. But, I think we are looking for sustainable partnerships. We know what Chinese products do to our market. It's fine when people have cheap products, everybody is happy until somebody loses a job. Then you see the argument in reverse. We don't want quick fixes. [...] Only integrated approaches can work, rather than looking at the particular short-term goals.

The perceptions in Kenya are slightly different. Certain business representatives, for instance, are quite positive about the role of the EU in Africa. Laban Onditi, ViceChairman of Kenya's Chambers of Commerce, believes that "the EU has played a very key role in the development of the country. Also looking at Africa as a region, there is no other foreign country playing such a major role as the EU." 28 However, as reported in Figure 2, $38 \%$ of the respondents think that the United States is a key competitor to the EU in Kenya. After the US, comes China (34\%), India (20\%) and the rest of Africa is last, with only $7 \%$. Nonetheless, the placement of China is worthy noting as it is Kenya's first emerging and alternative partner to the traditional Western counterparts. ${ }^{29}$

A former Member of Parliament and Cabinet Minister, speaking under anonymity, expresses strong preference for China as a developmental and economic partner. Although he acknowledges the significant role the EU plays in the development of the

27 N. Dollie, foreign news editors of The Mail \& Guardian. Interview held at the M\&G offices in Johannesburg (South Africa) on 25 September 2007.

${ }_{28}$ Mr. Laban Onditi, Vice Chairman, Kenya Chambers of Commerce. Interview held in Nairobi (Kenya) on 25 January 2008.

${ }^{29}$ Mr. Cryspus Ndinyo, Civil Engineer Norkin Consulting Engineers. Interview held in Lugulu (Kenya) on $8^{\text {th }}$ January 2008. 
country, he nevertheless voices concerns that accessing EU aid is a time-consuming process, often complicated by over-bureaucratic procedures:

For sure it would be difficult for our countries to survive were it not for the EU funds and even sometimes technical expertise. But the EU tends to exaggerate sometimes. If we go seeking funds from them with certain timetables, we also need to have the agreements and disbursement of funds done in a timely manner. Too often the EU takes a long time to release funds, and this becomes a huge a constraint for our government. Quite often these delays are due to the EU checking if we are adhering to human rights or democratic principles or on governance related issues.

It is specifically with respect to development aid that he draws a telling parallel with China by arguing that,

while we are still grappling with the EU's requirements, China comes in as a 'saviour.' Because if need to pay, say, teachers next year, we need to be sure that that the salaries will be available in time. The Chinese do not go into issues of governance, human rights and so forth (...). For them, it is business as usual. We sign an agreement with set timetables and the deal is done. They do not go into placing criteria that justify funding, after all let us all agree that these are soft loans which we have to pay at later stages after all. ${ }^{30}$

These positive remarks on China by some government officials are not matched by the views of certain members of business. Charles Mutuku, National Secretary of Kenya's Chambers of Commerce, identifies challenges with both the EU and China:

From the EU side, we are contemplating and debating over the extent to which we will open our market to European companies, because we fear that their goods could discourage enterprise development once we sign EPA agreements with them. The same can be said with China and even India. Their goods are even cheaper because of their poor quality. If think about it, the dumping of cheap goods onto the Kenyan market are a real danger for Kenyan business people and also for the EU, which is interested in its products here. ${ }^{31}$

Mr. Mutuku does acknowledge, however, that depending on the areas of business, the availability of cheaper products from China (or India) is welcome by local customers. This is the case for "medicines", for instance, "because so many people here in Kenya don't have enough money to pay for expensive EU or US patented pharmaceuticals". ${ }^{2}$

\subsection{Public opinion}

The analysis of public opinion by and large confirms the trends already identified through the review of elites' opinions. In South Africa, most respondents identified China as the

\footnotetext{
${ }^{30}$ A former Member of Parliament and Cabinet Minister, speaking under anonymity.. Interviewed on 18 January 2008 in Webuye (Kenya).

${ }_{31}$ Mr. Charles Mutuku, Secretary, Kenya Chambers of Commerce. Interviewed in Nairobi (Kenya) on 25 January, 2008.

32 Ibid.
} 
most important partner to their country (49\%), followed by the US (47\%). The EU/Europe comes only third, with slightly more than $30 \%$ (Figure 3 ). ${ }^{33}$

Figure 3 - Most important country/region for South African public opinion

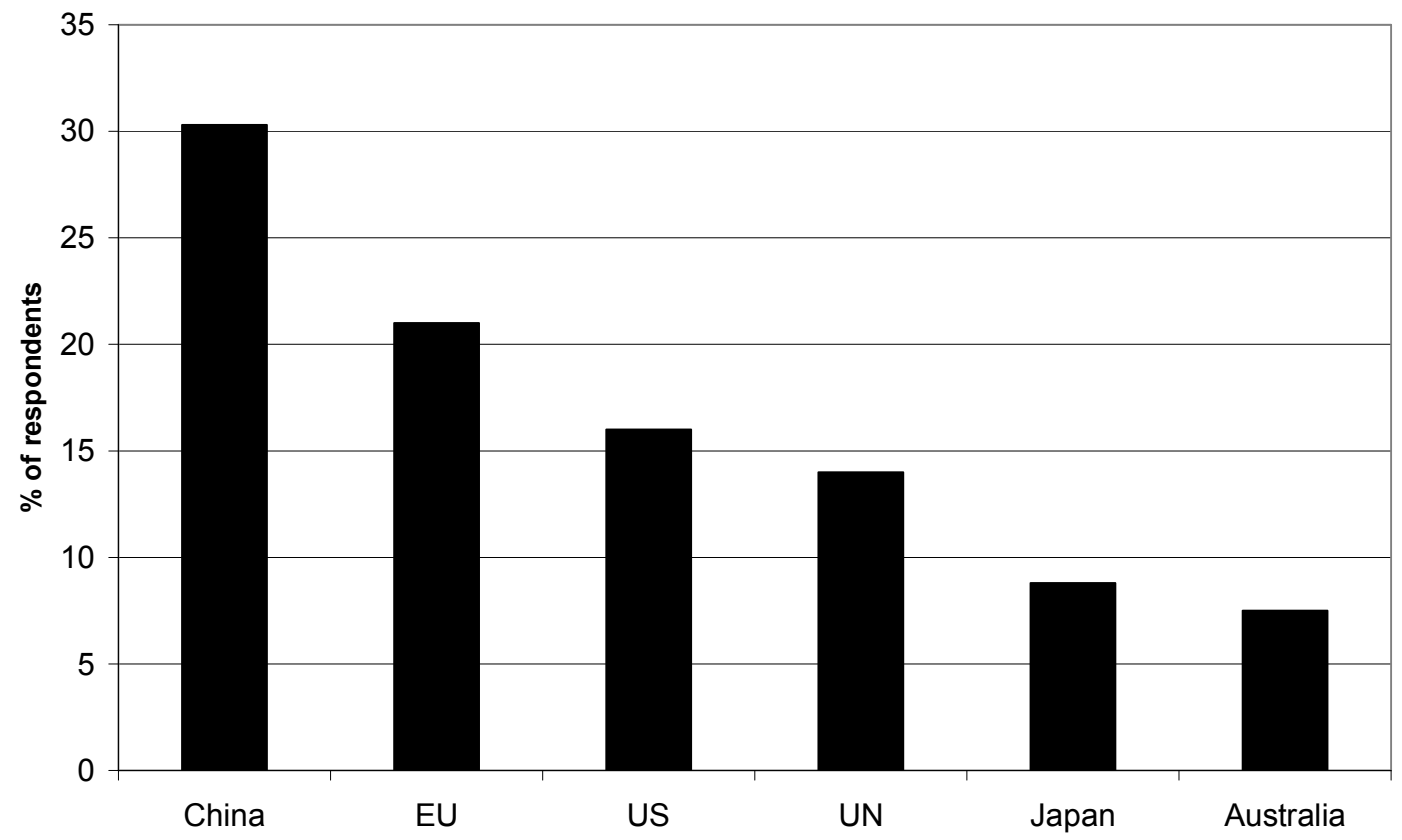

Source: National Centre for Research on Europe

While the relevance of the US is obviously related to the global importance of the 'only' super power, the primacy attributed to China is to be explained in light of its recent and burgeoning involvement in the African continent, which we discussed in Section 2. Most probably had we asked the same question a few years ago, China would have not even featured on the list. At times, China has also been viewed as a credible alternative (or 'counterforce') to Europe in the African quest for development. While some critics have warned against the long-term implication of Chinese policies across the continent, it appears that public opinion is overwhelmingly aware of what one might call the Chinese 'factor' in South Africa.

This is also confirmed by Figure 4, which shows that China is also the most important 'developmental' actor for the country.

33 Our dedicated opinion survey was conducted in South Africa's major cities and included specific questions on the EU and potential competitors. It was a stratified survey, representative of South Africa's urban population with a margin of error of $4 \%$. 
Figure 4 - The most important developmental actor for South Africa (public opinion's perceptions)

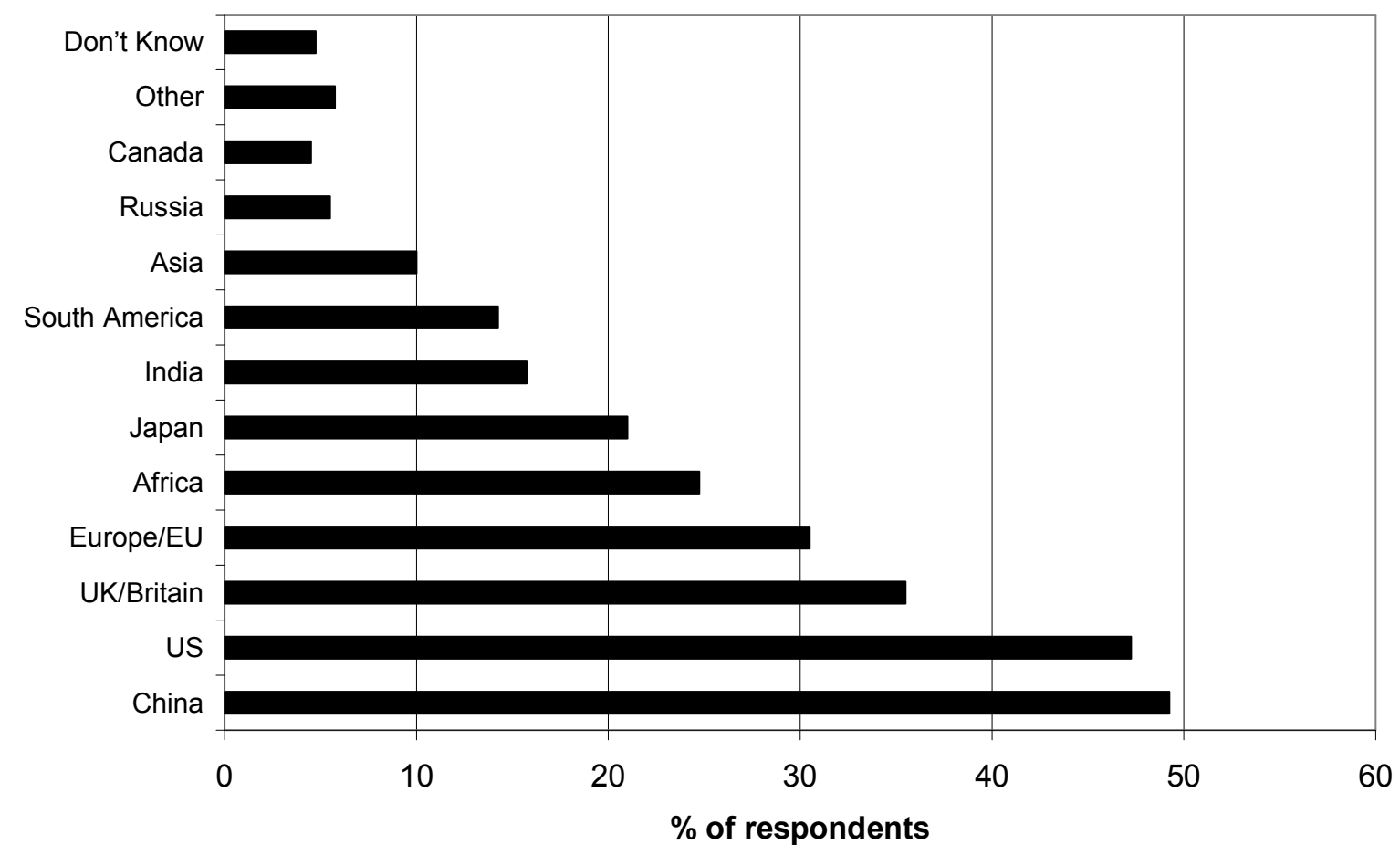

Source: National Centre for Research on Europe

Since it focuses on the developmental aspect, this is a particularly interesting result. Indeed, China is often described as a 'ruthless' power as opposed to the 'civilian power' of the EU. While China is commonly described as a real-politik global player by media outlets, the EU is generally portrayed as a benevolent actor concerned with human rights and peace in the African continent. Therefore, this prevalence of China as a development partner stands out. It is possible that China, due to its growing investment in the South African economy and its massive involvement in infrastructure building in the region, might be perceived by most South Africans as a more development-oriented player vis-àvis the EU, which is more concerned with 'softer' issues such as institution building and good governance. It must also be considered that, as discussed above, the reputation of the EU as a development partner was severely undermined by the EPA process in 2007-2008, which saw South Africa at the forefront of the bloc opposing the EU agenda in the region. It is not unlikely that this contrast at the political and economic level might have also influence public opinion's perceptions.

In the case of Kenya, we could not conduct a specific opinion survey (due to the critical security conditions in the country at the time) and therefore we have decided to analyse the Afrobarometer 2008, which only reports one generic question regarding the 'helpfulness' of various global actors to the respondents' countries. In Figure 5, we report the overall results of the Afrobarometer in Kenya, which broadly confirm the findings of our elite survey. ${ }^{34}$

\footnotetext{
${ }^{34}$ The Afrobarometer 2008 included three possible positive answers to the question "How much do you think that each of the following actors help your country?". The three responses were: "helping a lot", "helping somewhat", "helping a little bit".
} 
Kenyans view the UN as the most 'helpful' actor (with about $96 \%$ of overall positive responses), immediately tailed by the US, which is viewed positively by $92 \%$ of respondents (with 50\% of respondents maintaining that America has helped 'a lot'). The popularity of the US among Kenyan citizens is not surprising, especially if we consider that the survey was conducted at a time when presidential campaigns reached their peak in America as Barack Obama, whose father hailed from Kenya, was battling his way to the White House. The EU is in third position (with 90\%), followed by the African Union (88\%), while China attracts about $86 \%$ of positive views. Unlike the case of South Africa (but consistently with the survey of Kenyan elites), the Afrobarometer reveals that the EU is still given more consideration than China in Kenya, although the overall distance is rather limited and the gap appears to be closing. The most striking difference is to be found in the percentage of those who indicated the EU to be 'helping a lot' (42\%) and those who held the same opinion about China (25\%).

Figure 5 - Most 'helpful' global actor for Kenyan public opinion

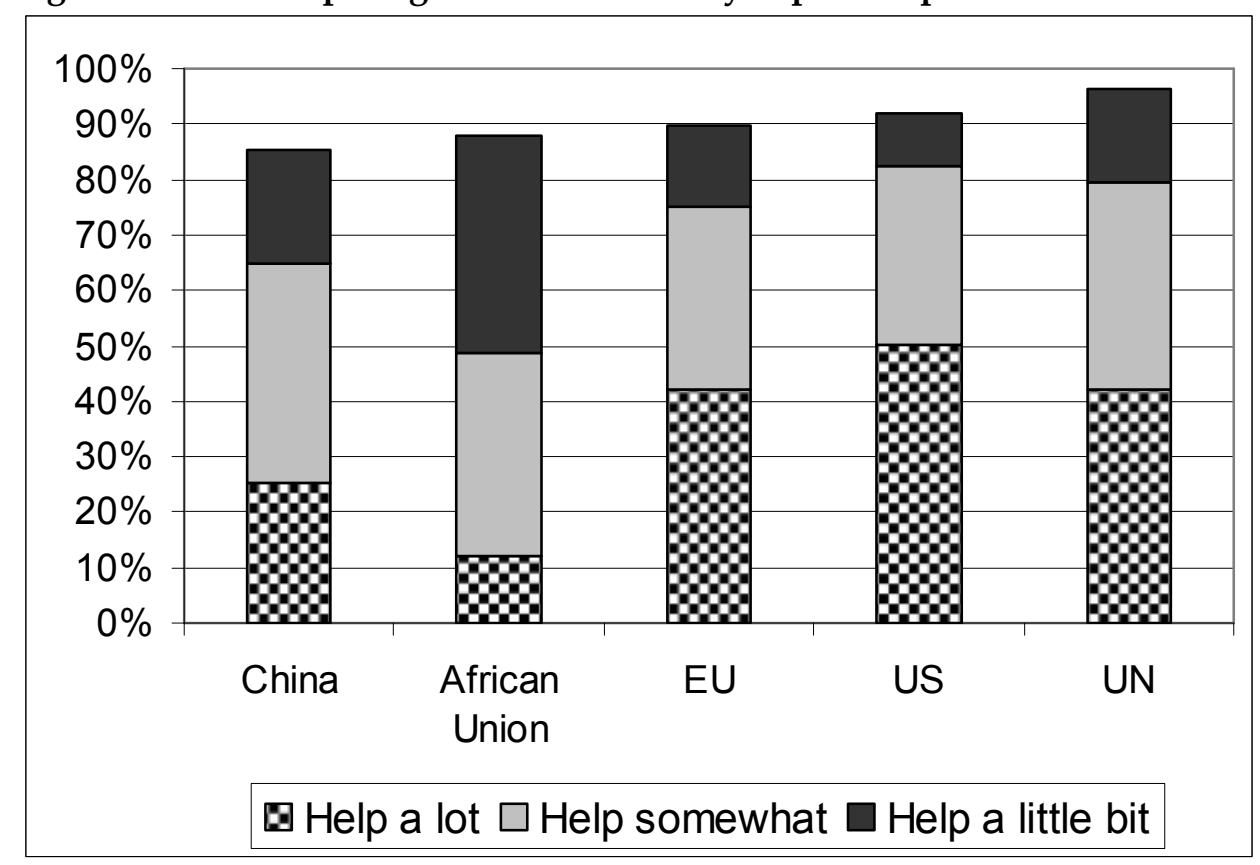

Source: Afrobameter, Round 2008 (www.afrobarometer.org)

\section{Conclusion}

No doubt Europe still has a strong foothold in Africa, mainly due to historical reasons, economic ties and political connections. Yet, the past few years have seen a gradual erosion of such a privileged relationship, particularly because of the growing financial investments made by China throughout the continent. Our empirical research, conducted in 2007-2008, confirms this overall depiction. If political leaders and businessmen emphasize the closeness between Africa and Europe, they also recognize that China is becoming more and more relevant by the day. Similarly, civil society leaders and media operators describe China as an opportunity for Africa to break free from its historical dependence on European markets: in their view, China would offer African countries an alternative to diversify their business and increase their overall payoffs. Public opinion data, too, attests to the growing relevance of China in the African context. 
At the same time, respondents in both countries are not necessarily convinced that China will eventually overtake Europe as the major trading and economic partner of the African continent. Although they are aware that a closer relationship with the Chinese might address short-term economic needs and help African economies diversify their foreign linkages, they are nevertheless suspicious of the long-term implications of this partnership. As some business leaders warned, it is still too early to gauge the extent to which China will become a reliable partner for African countries. Thus far, the relationship between China and Africa has mainly concentrated on the exploitation of natural resources. Its future developments will most probably depend on whether it will become a more far-reaching economic partnership capable of supporting long-term social development in Africa.

On the one hand, Europe is increasingly criticized for not having been able to dismiss the traditionally 'patronizing' attitude towards Africa, which dates back to the colonial era and still permeates the perceptions Africans hold of the EU. On the other hand, China is expected to bring a breath of fresh air into the African context, although there is still suspicion that the Chinese strategy might, in the long run, turn into a new form of economic patronage.

\section{Selected references}

Afrobarometer. A comparative series of national public attitude surveys on democracy, markets and civil society in Africa, Pretoria: IDASA, 2008.

Broadman, H. G. Africa's Silk Road: China and India's New Economic Frontier, Washington DC: The World Bank, (2006)

Buckens, M. M. "EU-Africa-China, a new triangular relationship?" The Courier, Issue No. III (N.S.), November/December 2007 < http:/ / www.acp-eucourier.info/EU-AfricaChina.174.0.html? \&L=1\%25B8>

Council of the European Union (2003), A Secure Europe in a Better World: European Security Strategy, Brussels, 12 December 2003.

Kaplinsky, R. and Morris. M. "China and the Terms of Trade: The Challenge to Development Strategy in Sub-Saharan Africa," Unpublished paper prepared for the Conference on the Rise of China - Global opportunities and challenges, Mount Holyoke, 2007.

Kernen, A. "Les strategies chinoises en Afrique: Du petrol aux bassines en plastique", Politique Africaine, No. 105, 2007, pp.163-180

Pillipe, R. (2007), 'Bruxelles accuse Paris de tenir un double discourse sur le commerce avec l'Afrique', Le Monde, 15 December 2007.

Reisen, H. and Ndoye, S. "Prudent versus Imprudent Lending to Africa: From Debt Relief to Emerging Lenders," OECD Working Paper, No. 268. Paris: OECD Development Centre, 2008.

Serge, M. "En Angola son premier partenaire africain, la Chine essuie pllusieurs", Le Monde, 24 May 2008.

Sylvanus, N. "Chinese Devils, the Global Market and the Declining Power of Togo's Commodity Queens", Politique Africaine, No.109, June 2008. 
UNCTAD. Asian Foreign direct investment in Africa: Towards a New Area of Cooperation Among developing countries, UNCTAD Current Studies on FDI and Development No. 3, Paris: UNCTAD, 2007.

Wade A. "Time for the West to Practise what it preaches," New African, March 2008, p.20.

FT.com. "China's New Scramble for Africa", Financial Times, 25 August 2010 $<$ http://www.ft.com/cms/s/0/d23c0066-b08a-11df-8c0400144feabdc0,dwp_uuid=5cdb1d20-feea-11db-aff2-000b5df10621.html>

Sicurelli, D. "Regional Partners? Perceptions and Criticisms at the African Union". In: External Perceptions of the European Union as a Global Actor, edited by S. Lucarelli and L. Fioramonti: 180-194. Routledge: London and New York, 2010.

Southall, R. and Melber, H. (eds), A New Scramble for Africa? Inperialism, Investment and Development. Pietermaritzburg: university of KwaZulu-Natal Press, 2009.

Roxburg, C. et al. Lions on the Move: The Progress and Potential of African Economies, Washington: McKinsey Global Institute, 2010. 